\title{
ANALISIS SISTEM PENGENDALIAN INTERNAL PEMBERIAN KREDIT PADA PD. BPR BANK DAERAH LAMONGAN
}

\author{
Yenni Vera Fibriyanti \\ Fakultas Ekonomi, Universitas Islam Lamongan \\ yennivera53@gmail.com \\ Oktavia Ikke Wijaya \\ Fakultas Ekonomi, Universitas Islam Lamongan \\ oktaviaikkew@gmail.com
}

\begin{abstract}
ABSTRAK
Penelitian ini bertujuan untuk (1) untuk menganalisa prosedur pemberian kredit PD. BPR Bank Daerah Lamongan. (2) untuk menganalisa sistem pengendalian internal pemberian kredit pada PD. BPR Bank Daerah Lamongan. Jenis penelitian yang digunakan adalah diskriptif kualitatif, karena penelitian ini dimaksudkan untuk menganalisa dan memperoleh gambaran tentang analisis sistem pemberian kredit dan penerapan sistem pengendalian intern pemberian kredit pada PD. BPR Bank Daerah Lamongan. Hasil penelitian ini menunjukkan bahwa prosedur pemberian kredit yang dilakukan oleh PD. BPR Bank Daerah Lamongan kepada debiturnya sangat efektif dengan prosentase sebesar 89,86\% karena telah sesuai dengan kebijakan-kebijakan yang diterapkan oleh Bank PD. BPR Bank Daerah Lamongan. Sistem pengendalian internal yang diterapkan pada PD. BPR Bank Daerah Lamongan sebesar 74,6 \% sehingga dapat dikatakan cukup efektif karena telah memenuhi unsur-unsur pengendalian internal yang ada.
\end{abstract}

Kata kunci : Sistem Pengendalian Internal, Pemberian Kredit

\section{PENDAHULUAN}

Dalam upaya mendukung

kesinambungan dan meningkatkan pelaksanaan pembangunan, lembaga perbankan telah menunjukkan perkembangan yang sangat pesat. Seiring dengan kemajuan pembangunan di Indonesia dan perkembangan perekonomian internasional, kemajuan yang dialami oleh lembaga perbankan dapat ditingkatkan secara berkelanjutan dan benar-benar memberi manfaat bagi masyarakat, sehingga dapat ditumbuh kembangkan menjadi suatu kekuatan yang riil bagi peningkatan kemakmuran rakyat.

Sebagaimana kita ketahui saat ini peranan bank sangat dirasakan manfaatnya baik oleh masyarakat maupun pemerintah. Karena bank adalah badan usaha yang menghimpun dana dari masyarakat dalam bentuk simpanan dan menyalurkannya kepada masyarakat dalam bentuk kredit dan atau 
bentuk-bentuk lainnya dalam rangka meningkatkan taraf hidup rakyat banyak (Kasmir, 2014 : 25). Dalam menyalurkan kredit ke masyarakat pihak bank dan masyarakat membutuhkan informasi. Informasi-informasi tersebut kemudian akan membentuk kesepakatan antara kedua belah pihak yang dituangkan dalam suatu perjanjian kredit.

Kredit adalah penyediaan uang atau tagihan yang dapat disamakan dengan itu, berdasarkan persetujuan atau kesepakatan antara bank dengan pihak lain yang mewajibkan pihak peminjam melunasi utangnya setelah jangka waktu tertentu dengan jumlah bunga, imbalan atau pembagian hasil keuntungan (Abdullah dan Tantri, 2012:163). Kredit bisa juga berarti kepercayaan (Sinungan, 1998:216). Kepercayaan itu adalah kepercayaan yang diberikan oleh bank kepada debitur yang akan nyata apabila kredit itu telah dikembalikan lagi beserta bunga (kontraprestasi) yang telah disepakati.

\section{Menurut Mulyadi (2013:163)}

Sistem Pengendalian Internal meliputi struktur organisasi, metode dan ukuran-ukuran yang dikoordinasikan untuk menjaga kekayaan organisasi, mengecek ketelitian, keandalan data akuntansi, mendorong efisiensi dan mendorong dipatuhinya kebijakan manajemen. Pengendalian internal tidak terlepas dari penjagaan pada prosedur pemberian kredit usaha dan tidak dimaksudkan menghilangkan semua kemungkinan terjadi kesalahan dan penyelewengan, tetapi bagaimana cara usaha-usaha pengkreditan dapat dihindarkan dari keborosan waktu, tenaga ataupun dana serta tidak tergantung pada sedikit dan banyaknya tahapan yang dilalui oleh debitur, tetapi pada tahapan yang telah dilakukan dengan baik dan benar.

Bank Perkreditan Rakyat (BPR), yaitu bank yang melaksanakan kegiatan usaha secara Konvensional atau berdasarkan prinsip syariah yang dalam kegiatannya tidak memberikan jasa dalam lalu-lintas pembayaran (Kasmir, 2014 : 35). PD. BPR Bank Daerah Lamongan merupakan salah satu Bank Perkreditan Rakyat yang ada di Lamongan yang dulunya dikenal sebagai Bank Pasar Lamongan. Didirikan oleh Pemerintah Kabupaten Lamongan pada tanggal 3 Desember 1952. Produk Kredit yang diberikan PD. BPR Bank Daerah Lamongan diantaranya yaitu KMK Bulanan, KMK Musiman, KMK Mingguan / Pasaran, Kredit PNS dan Kredit Perangkat. 
Berdasarkan latar belakang tersebut, tujuan yang ingin dicapai dalam penelitian ini adalah sebagai berikut:

1. Untuk menganalisa prosedur pemberian kredit PD. BPR Bank Daerah Lamongan.

2. Untuk menganalisa sistem pengendalian internal pemberian kredit pada PD. BPR Bank Daerah Lamongan

\section{TINJAUAN PUSTAKA}

\subsection{Bank Perkreditan Rakyat}

Menurut Kasmir (2014:14), bank adalah badan usaha yang menghimpun dana dari masyarakat dalam bentuk simpanan dan menyalurkannya kembali kepada masyarakat dalam bentuk kredit dan atau bentuk-bentuk lainnya dalam rangka meningkatkan taraf hidup rakyat banyak. Sedangkan usaha perbankan meliputi tiga kegiatan, yaitu menghimpun dana,menyalurkan dana, dan memberikan jasa bank lainnya.

Bank Perkreditan Rakyat adalah bank yang melaksanakan kegiatan usaha secara konvensional atau berdasarkan prinsip syariah yang dalam kegiatannya tidak memberikan jasa dalam lalu lintas pembayaran. BPR jauh lebih sempit jika dibandingkan dengan kegiatan bank umum (Kasmir, 2014:33) .
Landasan Hukum Bank Perkreditan Rakyat adalah UU No. 7 Tahun 1992 tentang Perbankan sebagaimana telah diubah dengan UU No. 10 Tahun 1998. Dalam Undang-undang tersebut secara tegas disebutkan bahwa BPR sebagai satu jenis bank yang kegiatan usahanya terutama ditujukan untuk melayani usaha-usaha kecil dan masyarakat di daerah pedesaan. Dalam pelaksanaan kegiatan usahanya BPR dapat menjalankan usahanya secara konvensional atau berdasarkan prinsip syariah.

Keunggulan yang dimiliki Bank Perkreditan Rakyat (BPR) terhadap Bank Umum terutama prosedur pelayanan yang sederhana, proses yang cepat, dan sistem kredit yang lebih fleksibel. Selain itu, BPR juga unggul dalam hal pelayanan kepada nasabah yang mengutamakan pendekatan personal dan mendatangi secara langsung nasabah, lokasi kantor yang dekat dengan nasabah, serta lebih memahami ekonomi dan masyarakat setempat. Dibandingkan dengan LKM non Bank, BPR memiliki keunggulan berupa adanya pengaturan, pengawasan, dan pembinaan oleh Bank Indonesia, serta adanya infrastruktur pendukung. 


\subsection{Pemberian Kredit}

Menurut Rivai et al (2007:4) kredit adalah penyerahan barang, jasa atau uang dari satu pihak (kreditor) atas dasar kepercayaan kepada pihak lain (nasabah atau pengutang) dengan janji membayar dari penerima kredit kepada pemberi kredit pada tanggal yang telah disepakati kedua belah pihak.

Menurut Kasmir (2014 : 88)

tujuan utama pemberian suatu kredit adalah sebagai berikut :

a. Mencari keuntungan

Bertujuan untuk memperoleh hasil dari pemberian kredit tersebut.

b. Membantu usaha nasabah

Untuk membantu usaha nasabah yang memerlukan dana, baik dana investasi maupun dana untuk modal kerja.

c. Membantu pemerintah

Bagi pemerintah semakin banyak kredit yang disalurkan oleh pihak perbankan, maka semakin baik, mengingat semakin banyak kredit berate adanya peningkatan pembangunan di berbagai sector.

Menurut Kasmir (2014:89-90) Disamping tujuan di atas fasilitas kredit memiliki fungsi sebagai berikut :

a. Untuk meningkatkan daya guna uang b. Untuk meningkatkan peredaran dan lalu lintas uang.

c. Untuk meningkatkan daya guna barang.

d. Meningkatkan peredaran barang.

e. Sebagai alat stabilisasi ekonomi.

f. Untuk meningkatkan kegairahan berusaha.

g. Untuk meningkatkan pemerataan pendapatan.

h. Untuk meningkatkan hubungan internasional.

Sebelum fasilitas kredit diberikan, bank harus merasa yakin bahwa kredit yang diberikan benar-benar akan kembali. Keyakinan tersebut diperoleh dari hasil penilaian kredit sebelum kredit tersebut disalurkan. Penilaian kredit oleh bank dapat dilakukan oleh beberapa cara untuk mendapatka keyakinan tentang nasabahnya, seperti melalui prosedur penilaian yang benar. Adapun prinsip-prinsip yang digunakan adalah berupa analisis $5 \mathrm{C}$ dan $7 \mathrm{P}$ menurut Kasmir (2014 : 95-98) : Character, Capacity, Capital, Colleteral, Condition, Personality, Party, Purpose, Prospect, Payment, Profitability, Protection.

\subsection{Sistem Pengendalian Internal}

Standar Akuntansi Seksi 319 Pertimbangan atas Pengendalian Intern 
dalam Audit Laporan Keuangan paragraf 06 mendefinisikan pengendalian intern sebagai suatu proses yang dijalankan oleh dewan komisaris, manajemen, dan personel lain yang di desain untuk memberikan keyakinan memadai tentang pencapaian tiga golongan tujuan berikut ini : Keandalan pelaporan keuangan, Kepatuhan terhadap hukum dan peraturan yang berlaku, Efektivitas dan efisiensi operasi.

Menurut Mulyadi (2013:163), Sistem pengendalian intern meliputi struktur organisasi, metode dan ukuran-ukuran yang dikoordinasi untuk menjaga kekayaan organisasi, mengecek ketelitian dan keandalan data akuntansi, mendorong efisiensi dan mendorong dipatuhinya kebijakan manajemen. Dengan terselenggaranya sistem pengendalian intern yang memadai dalam bidang perkreditan, berarti menunjukkan sikap kehati-hatian dalam bank tersebut. Sistem pengendalian intern yang efektif dapat membantu pengurus bank menjaga asset bank, menjamin tersedianya pelaporan keuangan dan manajerial yang dapat dipercaya, meningkatkan kepatuhan bank terhadap ketentuan dan peraturan perundang-undangan yang berlaku, serta mengurangi risiko terjadinya kerugian, penyimpangan dan pelanggaran aspek kehati-hatian. Terselenggaranya sistem pengendalian intern bank yang handal dan efektif menjadi tanggung jawab dari pengurus dan para pejabat bank. Evaluasi sistem pengendalian intern pemberian kredit harus sering dilakukan sehingga apabila ada suatu penyimpangan atau kesalahan dapat segera diketahui.

Unsur-unsur Sistem Pengedalian Intern menurut Mulyadi (2013: 183) adalah sebagai berikut :
a. Lingkungan pengendalian
b. Penaksiran resiko
c. Aktivitas pengendalian
d. Informasi dan komunikasi
e. Pemantauan atau pengawasan

\section{METODE PENELITIAN}

Jenis penelitian yang digunakan adalah diskriptif kualitatif, karena penelitian ini dimaksudkan untuk menganalisa dan memperoleh gambaran tentang analisis sistem pemberian kredit dan penerapan sistem pengendalian intern pemberian kredit pada PD. BPR Bank Daerah Lamongan.

Dalam penelitian kualitatif tidak mengenal istilah populasi, tetapi social situation atau situasi sosial yang terdiri atas tiga elemen yaitu : tempat, pelaku dan aktivitas yang berinteraksi secara 
sinergis. Situasi sosial dalam penelitian ini adalah (1) Kredit yang diberikan kepada nasabah sejak tahun 2016, (2) Seluruh karyawan PD. BPR Bank Daerah Lamongan. Sampel pada penelitian kualitatif bukan dinamakan responden, tetapi sebagai nara sumber, atau partisipan, informan, teman dan guru dalam penelitian. Sampel dalam penelitian ini yaitu: (1) Nasabah kredit mulai tahun 2016 sampai tahun 2017, (2) Karyawan bagian kredit, (3) Karyawan bagian sistem pengendalian intern.

Teknik pengambilan sampel yang digunakan adalah purposive sampling. Menurut Sugiyono (2011), purposive sampling adalah merupakan metode penetapan sampel berdasarkan kriteria tertentu. Kriteria yang digunakan untuk penarikan sampel dalam penelitian ini meliputi : (1) Karyawan yang bekerja minimal 1 tahun pada bagian kredit dan bagian sistem pengendalian intern, (2) Karyawan yang bekerja menangani proses pemberian kredit pada PD. BPR Bank Daerah Lamongan, (3) Karyawan yang berkerja menangani sistem pengendalian intern pada PD. BPR Bank Daerah Lamongan.

Pengolahan data yang dilakukan oleh peneliti menggunakan analisis sebagai berikut:
1. Mengumpulkan data dengan melakukan wawancara secara langsung dengan kepala unit, mantri/account officer pada bagian kredit untuk memperoleh data mengenai kebijakan dan aktivitas pemberian kredit pada PD. BPR Bank Daerah Lamongan

2. Membandingkan prosedur dan kebijakan pemberian kredit yang telah diterapkan dengan membagikan kuesioner yang berisi pertanyaan untuk memperoleh data mengenai kebijakan dan aktivitas pemberian kredit pada PD. BPR Bank Daerah Lamongan dengan teori yang menjadi landasan pada penelitian ini yaitu menggunakan analisis $5 \mathrm{C}$ dan $7 \mathrm{P}$.

3. Membagikan kuesioner yang berisi pertanyaan untuk memperoleh data mengenai kebijakan dan aktivitas pemberian kredit pada PD. BPR Bank Daerah Lamongan.

Hasil jawaban kueisioner dihitung menggunakan rumus berikut :

Presentase $=\frac{\text { Jumlah Jawaban "Ya" }}{\text { Jumlah Jawaban Kuesioner }} \times 100 \%$

Penulis menyediakan jawaban secara kuesioner secara tertutup, yaitu responden hanya memberi tiga alternatif jawaban yang telah ditentukan sebelumnya oleh penulis 
yaitu "Ya", "Tidak" atau "Tidak

Relevan". Sebagai ukuran tingkat kesesuaian dengan kriteria-kriteria tertentu sehingga responden cukup memilih salah satu jawaban yang dianggap paling cocok menurut responden dari ketiga alternatif jawaban tersebut. Untuk kepentingan hasil perhitungan persentase, penulis akan menggunakan ketentuan klasifikasi sebagai berikut:

1) $0 \%-25 \%=$ penerapan pengendalian internal Tidak Efektif dalam menunjang prosedur pemberian kredit.

2) $26 \%-50 \%=$ Penerapan pengendalian internal Kurang Efektif dalam menunjang prosedur pemberian kredit.

3) $51 \%-75 \%=$ Penerapan pengendalian internal Cukup Efektif dalam menunjang prosedur pemberian kredit.

4) $76 \%-100 \%=$ Penerapan pengendalian internal Sangat Efektif dalam menunjang prosedur pemberian kredit.

4. Melakukan evaluasi terhadap unsur-unsur sistem pengendalian intern yang telah diterapkan pada PD. BPR Bank Daerah Lamongan dengan melakukan evaluasi terhadap dokumen dan catatan akuntansi, wawancara, serta sistem pengendalian intern yang telah terstandar.

5. Mencari solusi terhadap masalah atau kendala yang dialami oleh PD. BPR Bank Daerah Lamongan dan menarik kesimpulan terhadap penelitian yang telah dilakukan.

\section{HASIL DAN PEMBAHASAN}

Dalam penelitian ini, penulis menyebarkan sebanyak 37 Kuesioner kepada responden di PD. BPR Bank Daerah Lamongan. Dengan tingkat pengembalian sebanyak 37 kuesioner atau sebesar $100 \%$. Pada deskripsi hasil kuesioner, penulis menyajikan hasil pertanyaan responden yang berhubungan dengan proses pemberian kredit dan yang berhubungan dengan sistem pengendalian intern di PD. BPR Bank Daerah Lamongan.

Deskripsi data kuesioner yang telah diisi oleh responden adalah sebagai berikut: 
Tabel 1. Deskripsi Data Hasil Kuesioner

\begin{tabular}{|c|c|c|c|c|c|}
\hline \multirow{2}{*}{$\begin{array}{l}\mathbf{N} \\
\mathbf{0}\end{array}$} & \multirow{2}{*}{$\begin{array}{c}\text { No. } \\
\text { Perta } \\
\text { nyaan }\end{array}$} & \multirow{2}{*}{$\begin{array}{c}\text { Jumlah } \\
\text { Pertany } \\
\text { aan } \\
\end{array}$} & \multirow{2}{*}{ Keterangan } & \multicolumn{2}{|c|}{ Prosentase } \\
\hline & & & & Ya & Tidak \\
\hline 1 & $1-12$ & 12 Soal & $\begin{array}{l}\text { Prosedur } \\
\text { pemberian } \\
\text { Kredit }\end{array}$ & $89,86 \%$ & $10,14 \%$ \\
\hline 2 & $13-21$ & 9 Soal & $\begin{array}{l}\text { Pengawasan } \\
\text { dan } \\
\text { Pemantauan } \\
\text { (SPI) }\end{array}$ & $56,76 \%$ & $43,24 \%$ \\
\hline 3 & $1-8$ & 8 Soal & $\begin{array}{l}\text { Lingkungan } \\
\text { Pengendalia } \\
\mathrm{n}(\mathrm{SPI})\end{array}$ & $81,08 \%$ & $18,29 \%$ \\
\hline 4 & $9-14$ & 6 Soal & $\begin{array}{l}\text { Penaksiran } \\
\text { Resiko (SPI) }\end{array}$ & $59,46 \%$ & $40,54 \%$ \\
\hline 5 & $15-24$ & 10 Soal & $\begin{array}{l}\text { Aktivitas } \\
\text { Pengendalia } \\
\text { n (SPI) }\end{array}$ & $78,65 \%$ & $21,35 \%$ \\
\hline 6 & $25-30$ & 6 Soal & $\begin{array}{l}\text { Informasi } \\
\text { dan } \\
\text { komunikasi } \\
\text { (SPI) }\end{array}$ & $81,98 \%$ & $18,02 \%$ \\
\hline & Imlah & 51 Soal & Total & $447,79 \%$ & $151,58 \%$ \\
\hline \multicolumn{4}{|c|}{ Rata-Rata } & $74,6 \%$ & $25,4 \%$ \\
\hline
\end{tabular}

Sumber: Data diolah

Tabel 5.4 merupakan deskripsi data hasil kuesioner yang telah dibagikan kepada karyawan PD. BPR Bank Daerah Lamongan, dengan jumlah pertanyaan sebanyak 52 soal dan jumlah jawaban ya $447,79 \%$, jawaban tidak $151,58 \%$, serta rata-rata sebesar $74,6 \%$.

\subsection{Analisis Prosedur Pemberian} Kredit PD. BPR Bank Daerah

\section{Lamongan}

Prosedur pemberian kredit yang dilakukan oleh PD. BPR Bank Daerah Lamongan kepada debitur mempunyai nilai prosentase kuesioner sebesar $89,86 \%$, artinya kebijakan-kebijakan yang telah diterapkan oleh PD. BPR Bank Daerah Lamongan sangat efektif dan sesuai dengan analisa kredit $5 \mathrm{C}$ dan 7P yang dilakukan oleh karyawan bagian analisa kredit terhadap calon debitur sehingga kredit sesuai tujuan dan tepat sasaran. Sistem pemberian kredit pada PD. BPR Bank Daerah Lamongan, dapat dijelaskan berdasarkan prosedur pemberian kredit berikut ini :

1. Prosedur permohonan pengajuan kredit

Dalam prosedur ini, pemohon kredit atau calon debitur harus memenuhi segala persyaratan yang telah ditentukan agar permohonan kreditnya dapat diproses. Setelah persyaratan tersebut telah dipenuhi, calon debitur kemudian mengajukan permohonan kredit dalam bentuk tertulis untuk memperoleh kredit pada PD. BPR Bank Daerah Lamongan dengan cara mengisi formulir (formulir permohonan kredit) dengan menggunakan format yang telah ditentukan oleh bank dan permohonan kredit dapat segera diproses. Selanjutnya, petugas akan mencatat formulir permohonan kredit calon debitur tersebut kedalam register. 
2. Prosedur Penyelidikan / Survey dan Analisa Kredit

Setelah permohonan kredit diajukan oleh calon debitur, selanjutnya pihak PD. BPR Bank Daerah Lamongan melakukan penyelidikan/survey untuk mencari data mengenai calon debitur. Penyelidikan/survey dilakukan melalui wawancara dengan calon debitur dan melakukan survey langsung ke tempat usaha calon debitur serta memeriksa kebenaran mengenai informasi yang telah disampaikan oleh nasabah.

Selanjutnya pihak PD. BPR Bank Daerah Lamongan melakukan analisa kredit terhadap permohonan kredit yang telah diajukan calon debitur. Dalam menganalisa kredit pihak PD. BPR Bank Daerah Lamongan menggunakan prinsip $5 \mathrm{C}$ dan $7 \mathrm{P}$ untuk memperoleh keyakinan agar kredit sesuai tujuan dan tepat sasaran.

3. Penyampaian Hasil Analisa Kredit Kepada Pemutus Kredit

Tahap ini akan diperoleh kesimpulan dari tahap analisa kredit yang dilakukan oleh pihak PD. BPR Bank Daerah Lamongan dengan menggunakan prinsip 5C dan 7P. Hasil analisa berupa pendapat dan saran yang akan disampaikan oleh analis kredit kepada pemutus kredit di PD. BPR Bank Daerah Lamongan yaitu Pimpinan Perusahaan (Direktur/Wakil direktur), dimana direktur akan membuat putusan kredit yaitu kredit tersebut diterima atau ditolak.

4. Hasil Persetujuan Permohonan Kredit

Tahap ini dimana permohonan kredit calon debitur akan diterima atau ditolak, jika prosedur permohonan kredit yang diajukan oleh calon debitur tidak diterima, maka semua berkas calon debitur mengenai permohonan kredit akan dikembalikan dan sebaliknya apabila prosedur permohonan kredit tersebut diterima, maka permohonan kredit debitur akan diproses, dan petugas Bank menyiapkan syarat-syarat fasilitas kredit dan prosedur yang akan ditempuh oleh debitur.

5. Perjanjian Kredit/ Penandatanganan Akad Kredit

Tahap ini setelah permohonan kredit debitur diterima, pihak Bank akan mengeluarkan Surat Keputusan Kredit dan Surat Pengikatan Jaminan dan melakukan penandatanganan perjanjian kredit dan pengikatan 
jaminan antara pihak debitur dan Bank secara resmi di depan notaris (Jika plafond jaminan diatas 10 juta) dengan notaris yang telah bekerjasama dengan PD. BPR Bank Daerah Lamongan.

6. Proses Pencairan Kredit

Pada tahap ini, setelah kredit diterima hal yang dilakukan selanjutnya yakni penandatanganan perjanjian kredit dan pengikatan jaminan antara debitur dan pihak PD. BPR Bank Daerah Lamongan, maka proses pencairan dapat segera dilakukan yaitu melalui pencairan tunai atau rekening tabungan di PD. BPR Bank Daerah Lamongan. Sehingga debitur dapat segera menggunakan dana tersebut sesuai dengan tujuan permohononan kredit yang telah diajukan.

7. Prosedur Pelunasan Fasilitas Kredit

Pelunasan yaitu dipenuhinya semua hutang debitur terhadap bank yang mengakibatkan hapusnya perikatan perjanjian kredit. Semua kewajiban debitur harus diselesaikan sampai tanggal pelunasan yang meliputi utang pokok dan utang bunga. Bank akan mengatakan kepada debitur bahwa kredit telah lunas, apakah ingin dipakai lagi atau tidak. Apabila debitur memakai lagi setelah dilakukan evaluasi oleh analis kredit dan pimpinan yang berwenang maka bank akan memperpanjang kreditnya. Namun jika tidak diperpanjang lagi maka bank harus mengembalikan semua dokumen milik debitur dalam keadaan bersih dan begitu pula bank akan menerima tanda terima serta member tanda kredit lunas.

\subsection{Analisis Sistem Pengendalian} Internal Pemberian Kredit pada PD. BPR Bank Daerah

\section{Lamongan}

Sistem pengendalian intern yang dilakukan oleh PD. BPR Bank Daerah Lamongan sudah berjalan efektif dan cukup baik, hal ini ditunjukkan dengan rata-rata hasil kuesioner sebesar 74,6 \%. Berikut analisa sistem pengendalian intern pemberian kredit yang dilakukan oleh PD. BPR Bank Daerah Lamongan:

1. Lingkungan Pengendalian

Lingkungan pengendalian yang ada pada PD. BPR Bank Daerah Lamongan dapat dikatakan sangat efektif dengan nilai prosentase sebesar 81,08\%. Karena setiap tahunnya terdapat audit eksternal dari Kantor Akuntan Publik (KAP) dan pengawasan audit oleh Otoritas Jasa 
Keuangan (OJK). Kantor Akuntan

Publik (KAP) melakukan pemeriksaan umum atas laporan keuangan PD. BPR Bank Daerah Lamongan untuk menghasilkan keakuratan laporan keuangan yang ada pada PD. BPR Bank Daerah Lamongan.

2. Penaksiran Risiko

Penaksiran resiko yang ada pada PD. BPR Bank Daerah Lamongan sudah baik dengan nilai prosentase sebesar $\quad 59,46 \%$. Untuk mengantisipasi dan mengurangi adanya kredit macet atau bermasalah yang disebabkan oleh berbagai macam faktor seperti adanya nasabah yang pindah alamat rumah, nasabah meninggal, atau bangkrutnya usaha nasabah, PD. BPR Bank Daerah Lamongan menerapkan kebijakan-kebijakan yang ditujukan pada debiturnya, yaitu dengan memantau perkembangan usaha debitur, dan Bank melakukan penagihan kepada debitur kredit macet.

3. Aktivitas Pengendalian

Aktivitas pengendalian pada PD. BPR Bank Daerah Lamongan memiliki prosentase $78,65 \%$ ini dapat dikatakan sangat efektif.
Dalam meminimalkan kredit macet seperti tidak tertagihnya kredit yang telah diberikan, PD. BPR Bank Daerah Lamongan mempunyai tahapan-tahapan dalam penyelamatan dan penyelesaian kredit macet dengan cara non litigasi, restrukturisasi kredit hingga dengan cara litigasi.

4. Informasi dan Komunikasi

Informasi dan komunikasi PD. BPR Bank Daerah Lamongan memliki prosentase $81,98 \%$ ini dapat dikatakan sangat efektif. PD. BPR Bank Derah Lamongan mempunyai Sistem Layanan Informasi Keuangan (SLIK), dengan SLIK pihak bank dapat melihat data mengenai calon debitur, apakah sudah terdaftar kredit pada bank lain atau tidak, serta memberikan informasi kepada unit kerja yang lain bahwa calon debitur layak menerima kredit atau tidak.

5. Pemantauan dan Pengawasan

Pemantauan dan Pengawasan pada PD. BPR Bank Daerah Lamongan memiliki prosentase $56,76 \%$ ini dapat dikatakan cukup efektif. Pemantauan debitur dilaksanakan oleh analis kredit, analis kredit PD. BPR Bank Daerah 
Lamongan melakukan pemantauan dan pengawasan terhadap perkembangan usaha nasabah, serta adanya buku harian kunjungan nasabah sehingga dapat mengetahui perkembangan usaha nasabah.

Sistem Pengendalian Intern yang ada pada PD. BPR Bank Daerah Lamongan cukup efektif dalam bidang perkreditannya, yakni dengan rata-rata hasil jawaban sebesar 74,6\% . Dimana sesuai dengan penelitian yang dilakukan oleh Amira Ahmad pada tahun 2013, nilai prosentase sebesar $74,6 \%$ dikategorikan Cukup Efektif.

PD. BPR Bank Daerah Lamongan juga mempunyai struktur organisasi yang jelas dan pembagian tugas karyawan yang baik sesuai dengan kemampuan masing-masing karyawan. Hal ini menunjukkan bahwa sistem pengendalian internal pada PD. BPR Bank Daerah Lamongan sudah sesuai dengan teori-teori sistem pengendalian intern yang ada yakni: Lingkungan Pengendalian, Penaksiran Resiko, Aktivitas Pengendalian, Informasi Dan Komunikasi, dan Pemantauan/Pengawasan sehingga dapat mendorong tercapainya pemberian kredit yang cukup efektif pada debitur.

\section{PENUTUP}

\subsection{Simpulan}

Berdasarkan hasil penelitian dan pembahasan di atas, dapat disimpulkan bahwa :

1. Prosedur pemberian kredit yang dilakukan oleh PD. BPR Bank Daerah Lamongan kepada debiturnya sangat efektif dengan prosentase sebesar $89,86 \%$ karena telah sesuai dengan kebijakan-kebijakan yang diterapkan oleh Bank PD. BPR Bank Daerah Lamongan.

2. Sistem pengendalian internal yang diterapkan pada PD. BPR Bank Daerah Lamongan sebesar 74,6\% sehingga dapat dikatakan cukup efektif karena telah memenuhi unsur-unsur pengendalian internal yang ada.

\subsection{Saran}

1. PD. BPR Bank Daerah Lamongan sebaiknya membuat buku laporan mengenai perkembangan usaha nasabah yang digunakan untuk mengetahui apakah kredit yang diberikan Bank telah digunakan sebagaimana mestinya dan untuk mengetahui apakah kredit yang diberikan dapat membantu usaha nasabah menjadi lebih berkembang. 
2. Diharapkan adanya minimal dan maksimal pemantauan terhadap usaha nasabah yang dilakukan oleh pihak PD. BPR Bank Dearah Lamongan sehingga dapat memantau usaha nasabah tersebut berkembang atau tidak.

3. Untuk peneliti selanjutnya diharapkan lebih mengembangkan materi penelitian dengan menambah variabel dan sampel tahun penelitian.

\section{DAFTAR PUSTAKA}

Abdullah Thamrin dan Francis Tantri, 2012., Bank dan Lembaga Keuangan, Jakarta: PT. Raja Grafindo Persada

Hadi dan Rahayu, 2014., Sistem Pengendalian Internal Pemberian Kredit pada Bank Danamon Cabang Kembang Jepun Surabaya, Jurnal Ilmu\&Riset Akuntansi Vol. 3 No.11. Hal 1-16

Kasmir, 2009., Bank dan Lembaga Keuangan Lainnya, Edisi Revisi, Jakarta: Penerbit PT Raja Grafindo Persada

Mulyadi, 2010., Sistem Akuntansi, Jakarta : Salemba Empat

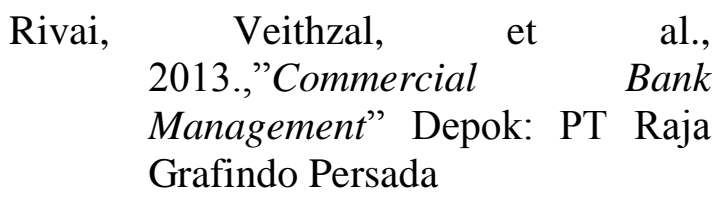

